\title{
Protection of Minority Shareholder Investment in the Small and Medium-sized Enterprises
}

\author{
Chinnapat KANTHAPANIT ${ }^{1}$, Chutiya KANTHAPANIT ${ }^{2}$
}

Received: May 05, 2020 Revised: May 31, 2020 Accepted: July 03, 2020

\begin{abstract}
This study aims to examine the relationship of the four factors that increase the protection of minority shareholder investment. The factors are non-controlling shareholders, corporate governance, free cash flow, and shareholder wealth. The data for this study is obtained from the 2017 annual reports of 136 Thai public companies listed in the Market of Alternative Investment of Thailand (MAI). The analysis uses a multiple regression model to determine which factors encourage and which inhibit the protection of minority shareholder investment. The study tests four hypotheses. The results rejected $\mathrm{H} 1$ because non-controlling shareholders have negatively correlated with minority shareholder investment protection (beta -0.155 and p-value 0.050 ). The results accepted H2, H3 and H4 as follows. H2: corporate governance has positively correlated with minority shareholder investment protection (beta 0.17 and p-value 0.031 ). H3: free cash flow has positively correlated with minority shareholder investment protection (beta 0.214 and p-value 0.007 ). H4: shareholder wealth has positively correlated with minority shareholder investment protection (beta 0.318 and p-value 0.000 ). The major findings suggest strong minority shareholder investment protection was enhanced by increasing corporate governance, free cash flow and shareholder wealth. The protection of minority shareholder investment needs to reduce non-controlling shareholding pattern.
\end{abstract}

Keywords: Small and Medium-sized Enterprises, Minority Shareholder, Investment Protection, Corporate Governance, Cash Flow, Shareholder Wealth

JEL Classification Code: G30, G32, G34

\section{Introduction}

The Organization for Economic Co-operation and Development (OECD) identified outside investor protection as supportive of the development of corporate governance, which in turn leads to benefits that include the financial stability of creditors, corporations, and capital markets in the long run (Croci \& Petmezas, 2010).

Investor protection therefore encourages suppliers of finance to corporations and assured themselves of getting

${ }^{1}$ First Author and Corresponding Author. Lecturer, Faculty of Accounting and Management, Mahasarakham University, Thailand [Postal Address: 141/19 Banhao Villege, Thenanon Road, Tumbon Talad, Meung, Mahasarakham 44000, Thailand]

Email: chinapat.k@acc.msu.ac.th

${ }^{2}$ Lecturer, Faculty of Accounting and Management, Mahasarakham University, Thailand. Email: chutiya.k@acc.msu.ac.th

(C) Copyright: The Author(s)

This is an Open Access article distributed under the terms of the Creative Commons Attribution Non-Commercial License (http://Creativecommons.org/licenses/by-nc/4.0/) which permits unrestricted noncommercial use, distribution, and reproduction in any medium, provided the original work is properly cited. a return on their investment (Shleifer \& Vishny, 1997). Minority shareholders (Free Float) means the shareholders who are not the strategic shareholders playing roles in managing the company (Stock Exchange of Thailand, 2020). Minority shareholders hold shares less than $25 \%$ of all eligible voting shares. The strategic shareholders are controlling shareholders who exert influence over policymaking, management, or the operation of the company. They also have shares amounting for more than $5 \%$ of paidup capital of the company (Stock Exchange of Thailand, 2020). The risk of minority shareholder expropriation is the major principal-agent problem for public corporations. Expropriation is defined as the process of using one's controlling powers to maximize one's own welfare and redistribute wealth from minority shareholders. (Claessens, Djankov, Fan, \& Lang, 1999).

Poor corporate governance is associated with selfdealing behavior of management, which can be toxic to the minority shareholders. Improving the roles of protection of small shareholder investment enhances investor power to acquire more benefits from management (Claessens, et 
al., 1999). Investor protection literature in Asia suggested good protection is supported by dispersed ownership, strong legal protection, and good corporate governance standard in the country. Asian countries believed corporate governance standard encourage investor protection because corporate governance is the system of controls that helps the corporation effectively manage, administer, and direct economic resources benefiting stakeholders (OECD, 2015). Corporate governance also helps managers and directors have an implicit obligation to ensure that firms are run in the interests of shareholders (Maher \& Andersson, 1999). Much research suggested that separation of ownership and control creates conflict of interests. Agency problem is the cause of poor investor protection because managers are employee. They have no bearing on the cost of doing business, or gain the full benefits, of their actions. In contrast to agency problem, whereas shareholders are interested in maximizing shareholder value, managers may have other objectives such as maximizing their salaries, growth in market share, or an attachment to particular investment projects (Maher \& Andersson, 1999).

Corporate ownership in developing countries is in the hands of a small number of investors with significant power in control rights and cash flow rights. Legal protection does not give enough control rights to small investors in monitoring management (Claessens et al., 1999; Shleifer \& Vishny, 1997). Large shareholders are controlling shareholders, which in turn control the composition of the board of directors and influence the corporation's activities. They manage businesses from a self-serving perspective and have a track record of appointing board members, authorized by those families in control of firms, which arguably signals a conflict of interests between controlling shareholders and outside investors (Claessens et al., 1999; Nam \& Nam, 2004). Much research show controlling shareholders have been supported by legal institutional arrangements that enable the exercise of a high degree of control over a firm, and the deviation from the one-share-one-vote rule (Croci \& Petmezas, 2010). This has led to the expropriations. Large shareholders also are provided with the absence of mandatory disclosure of connected interests, a fertile ground for the self-dealing that resulted in a form of expropriation (Eldomiaty \& Choi, 2006).

This paper draws on previous research to identify the relevant factors and develop a theoretical basis for the study; it presents the research questions and hypotheses, the statistical model that guided the analysis and the results.

\section{Literature Review}

Previous studies of minority shareholder rights have found that it is related to the study of 'The Modern Corporation and Private Property’ described by Berle and Means (1932) who viewed shareholders as the legal owners of corporation who in turn appointed managers to manage the firm (Berle $\&$ Means 1932). Berle and Means (1932) recommended the separation between ownership and control theory, which describes the evaluation of market-based control factors. They showed parallels between the development of contract theory and agency theory. Agency theory describes the agency problem resulting from the conflict of interests between principal (shareholders) and agent (managers). While Contract theory addresses the incomplete nature of contracts and their role in explaining the problems of shareholder rights expropriation (Berle \& Means, 1932), the theory suggests the agency problem decreases in some businesses because management focuses on the protection of shareholder interests (Jensen \& Meckling, 1976).

A conflict of interests between managers and shareholders also involves cash. The free cash flow theory proposed by Jensen (1986) stated that managers may avoid a conflict of interests by not using cash from companies to fund inefficient projects or benefits themselves at the expense of shareholders. They should have responsibility to manage the company in the goal of shareholder wealth maximization. The accountability of management also refers to the evidence of managers' retaining unprofitable operations, resisting takeovers, and pursuing short-term profits. This led to the conflicts of interest between management and shareholders (Jensen, 1986). The substantial free cash flow generation is also a basic requirement for protecting the interests of minority shareholders. Protecting the rights of minority shareholder investment also relates to corporate governance theory. This is because corporate governance increase shareholder's power to monitor management (Shleifer \& Vishny, 1997).

Research into the protection of minority shareholder investment in Asian countries suggested controlling shareholders dominated outside investor expropriations, which are characterized as family-controlled ownership. Expropriations emerge when high control rights exceeded cash flow rights (Claessens et al., 1999). This is because the control rights allowed managers to transfer cash and assets out of the company for creating their own wealth. For example, the controlling shareholders can pursue selfserving actions that do not correspond to the interests of other stakeholders. Large shareholders exercise their control rights to redistribute wealth in both efficient and inefficient ways. This cost of concentrated ownership becomes particularly important for others such as minority investors (Shleifer \& Vishny, 1997). Many cases in Thailand showed controlling shareholders are also in management. They supported softterm loans to their business parties and transferred money to offshores business (Siamwalla, 2001; Sundaravej \& Trairatvorakul, 1989). Capital movement also associated with frauds, money laundering, and insider trading, creating window-dressing accounts and further created large capital 
outflow to their account overseas (Johnson, Booneb, Breachc, \& Friedmand, 2000).

All of the cases suggested controlling shareholders were able to steal cash and assets from corporations without monitoring by outside shareholders (Shleifer \& Vishny, 1997). Poor protection of minority shareholders investment relates to a conflict of interests between different types of controlling shareholders in the same company. For example, if a controlling shareholder is a major shareholder, it may influence the company to take high risk investment, while the other large shareholders, who are creditors, require good investment projects because they underwrite some of the cost, while the benefits contribute to the shareholders (Jensen \& Meckling, 1976; Shleifer \& Vishny, 1997).

The benefice to large investors is that they increase shareholder value. This is because they are better at monitoring managers and reduce transaction costs in negotiating and enforcing corporate contracts with various stakeholders (Shleifer \& Vishny, 1997). The following literature review provides more specific details of factors that related to the protection of minority shareholder investment.

\subsection{Non-Controlling Shareholders}

Development of market capitalization is associated with greater ownership diffusion. They are non-controlling shareholders who encourage management monitoring and equitable treatment of shareholders in a company (OECD, 2015). There are included in shareholder meeting, which finally creates best practices of corporate governance and strong protection of minority shareholder investment. In addition, the ineffectiveness of the corporate governance system of East Asian countries derived from the expropriation of minority shareholder rights. For example, controlling shareholders make decisions based on their own interests (Shleifer \& Vishny, 1997). They also have majority voting power that can be able to discharge board of members and managers who did not meet their expectations. This is cause for conflict of interests between controlling shareholders and minority shareholders that is related to protection of the rights of small investors (Nam \& Nam, 2004). The agency problem is the conflict of interests between owners and managers. However, in Thailand, the problem is different because the agency problem arises from the conflict of interest between large owners and small owners. This is because voting in a company is not based on one person-one-vote. That is why "controlling shareholders" have an increased opportunity to steal the profits of firms to advantage themselves rather than sharing profits with small investors (Johnson et al., 2000).

\subsection{Corporate Governance}

Corporate governance issued in the Stock Exchange Thailand (SET) guidelines were intended to compensate for deficiencies in a country's corporate governance system regarding the protection of shareholder rights. They were to ultimately assure the integrity of a firm's corporate governance in regard to such issues as takeovers, the legal environment, and shareholders' rights protection (Aguilera \& Cuervo-Cazurra, 2004). Research reveals that good corporate governance practices are associated with the protection of minority shareholder investment because corporate governance encourages small shareholders to monitor management, which resulted in the improvement of quality of companies' boards of governance, transparency and increase the accountability of companies to shareholders while maximizing shareholder wealth (Aguilera \& CuervoCazurra, 2004).

\subsection{Free Cash Flow}

Free cash flow (FCF) is the cash left over after a company pays for its operating expenses and capital expenditures. Strengthening small shareholder investment protection creates more power of small investors to extract cash from management. This is because managers may misuse cash flows for their own interests such as paying remuneration, and investing in inefficient projects, which return low compensation to small investors. These misleading activities may result in insufficient cash flows, which in turn lead banks into bankruptcy (Solomon \& Solomon 2004). However, should a firm prevent bankruptcy by seeking further funds, which all financial suppliers provide at additional cost of capital, all of these expenses would decrease firm performance and shareholder returns (Claessens et al., 1999). This finding was also consistent with Jensen (1986) who suggested that free cash flow was cash flow in excess of that required to fund projects that have positive net present values when discounted at relevant costs of capital. Conflicts of interests between shareholders and managers over dividend payments were especially severe when an organization generated substantial free cash flow. The problem was how to motivate the managers to disgorge the cash rather than investing it below the costs of capital or wasting it in inefficient organizational activities (Jensen, 1986). Strengthening minority shareholder rights can provide more cash flows because the rights give power to minority owners to control a manager's misdirected policy. This may result in improved firm performance and higher dividend payments, which become available due to the freed up free cash flow (Claessens et al., 1999).

\subsection{Shareholder Wealth}

Strong minority shareholder protection leads to shareholder wealth maximization. This is because the protection of minority shareholders is beneficial for monitoring managers who protect their self-interests by 
not paying out dividends, or transferring profits to other companies they control. Good protections provide the effective management and strong operational capabilities, which increase higher cash-flow rights and higher capital gains from their investment (Shleifer \& Vishny, 1997; Sturm \& Nüesch, 2019). There is an expropriation of minority shareholder rights through the pursuit of nonprofitmaximizing objectives by large investors who are also managers (Controlling shareholders). Investing in these companies are unattractive to small shareholders and their shares are valued less relative to their corporate market valuation (Sturm \& Nüesch, 2019). That is why firms with greater controlling shareholders normally created higher control rights that have an insignificant or negative effect on shareholder's market valuation (Sturm \& Nüesch, 2019)

\section{Research Framework and Hypotheses}

While all these studies provide evidence that the above factors influence minority shareholder investment protection, none has examined the integrated impact of all of them on the SMEs sector. This study fills this gap by investigating how minority shareholder investment protection is affected by non-controlling shareholders, corporate governance, free cash flow, and shareholder value. The research question is: Does the presence of non-controlling shareholders, corporate governance, free cash flow, and appropriate shareholder wealth enhance minority shareholders investment protection?

The hypotheses drawn from a research question and stated in $\mathrm{H} 1-\mathrm{H} 4$ are as follows:

Hypothesis 1 is based on the literature that suggested noncontrolling shareholders governed the firm and improved the protection of the interests of minority shareholders. This is because, when the power of control a corporation is in hands of controlling shareholders, they may exploit corporate resources for their self-interests at the expense of minority shareholders (Shleifer \& Vishny, 1997). Hypothesis 1 is as follows.

H1: Non-controlling shareholders have positively impacted upon minority shareholder investment protection

Minority shareholders are suppliers of finance to the corporations. They are deservedly receiving good investment returns. The literature review suggests strong corporate governance in regards to the protection of minority shareholders helps to reduce a conflict of interest between managers and shareholders. Good corporate governance also provided minority shareholders to monitor management. Hypothesis 2 is as follows.

H2: Corporate governance has positively correlated with minority shareholder investment protection
Free Cash Flow theory of agency costs suggests that a conflict of interests between managers and shareholders reduces because management generates excessive cash flow, enough at positive not present value (NPV) levels of their business investment (Jensen, 1986). Free Cash Flow is provision to supply for company's project investment and future growth, which benefits to the wealth of minority shareholders over the long run. The return to minority shareholders is also required cash flow because company can pay dividend if they have sufficient cash. Hypothesis 3 is as follows.

H3: Free Cash Flow has positively correlated with minority shareholder investment protection

The absence of separation between ownership and control reduces conflicts of interest and, thus, increases shareholder wealth. Shareholder wealth has a positive relationship with protection of minority shareholder rights because corporate governance of non-controlling shareholders support good monitoring on management that enriches shareholder value (Claessens et al., 1999). In contrast, investing in companies with greater controlling shareholders increases higher control rights than cash flow rights. This result has negative impacts on shareholder value (Shleifer \& Vishny, 1997). Hypothesis 4 is as follows.

H4: Shareholder wealth has positively correlated with minority shareholder investment protection

Figure 1 shows four independent variables (noncontrolling shareholders, corporate governance, free cash flow, and market value of company) and a dependent variable viewed as minority shareholder investment protection. The independent variables are hypothezised to have positive relationship with minority shareholder investment protection. The findings of hypotheses will answer what factors improve the protection of minority shareholder investment.

\section{Data and Methodology}

All listed companies in the Market for Alternative Investment (MAI) were selected for investigation. The MAI is the market for listing securities of small- and mediumsized enterprises (SMEs) established by the Stock Exchange of Thailand (SET). The secondary data are collected from the 2017 annual report in the form of FM56-1 of 136 listed companies in the MAI (The Stock Exchange of Thailand, 2017). The measures are shown as follows.

\subsection{Protection of Minority Shareholder Investment}

Minority shareholder protection has become an area of concern as part of the overall effort to improve corporate 


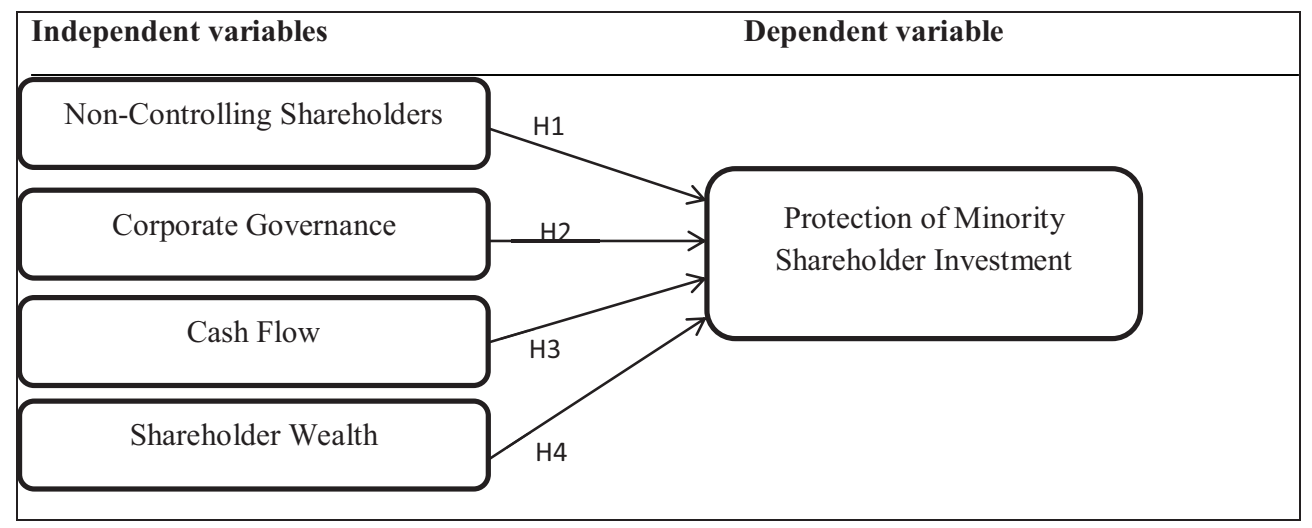

Figure 1: Research Frameworks and Hypothesis

governance. The protection of shareholder investment ensures the power of non-controlling shareholders who do not have voting control of a firm, and have the rights attach to securities that give investors the power to extract returns from their investment. Shareholders receive dividends because they can vote out the directors who do not pay them, and creditors are paid because they have the power to repossess collaterals. Without the rights, investors would not be able to get paid, and therefore firms would find it harder to raise external finance. The conflicts of interest between large and small shareholders derived from controlling shareholders enriching themselves by not paying out dividends, or transferring profits to other companies they control and nonprofit-maximizing objectives by large investors (Claessens et al., 1999, P.5). Dividend represents the effective corporate governance to ensure the benefits of minority shareholders. The protection of minority shareholder investment in this study is measured by Dividend yield provided by The Stock Exchange of Thailand data base (The Stock Exchange of Thailand, 2018).

\subsection{Non-Controlling Shareholders}

The information about ownership structure is drawn from annual financial reports in 2017 (The Stock Exchange of Thailand, 2018). The sample excludes a company that has symbolic NC, which is "Non-Compliance" and temporary unlisted in the market. Non-controlling shareholders are presented when a company has no shareholders who have either a direct or indirect vote of greater than $25 \%$ of all eligible voting rights. Non-controlling shareholders are rated by dummy scores such as Yes $=1$ or No $=0$.

\subsection{Corporate Governance}

Corporate governance is the rules and practices that govern the relationship between the managers and shareholders of corporations, as well as stakeholders, such as employees and creditors. Good corporate governance contributes to growth and financial stability by underpinning market confidence, financial market integrity and economic efficiency (OECD, 2004, p. 1). Corporate Governance assessment of the SET is rating scores from 0 to 5 . The data are collected from Corporate Governance report of Thai listed companies 2017 provided by the Stock Exchange of Thailand (SET) (The Stock Exchange of Thailand, 2018).

\subsection{Cash Flow}

Cash flow is measured by free cash flow in excess of that required to fund all projects that have positive NPV when discounted at the relevant cost of capital (Jensen, 1986). Free cash flow is measured by the following formula (Brigham \& Ehrhardt, 2004).

Free Cash Flow = Operating Cash Flow - Gross investment in operating capital.

Where, Gross investment in operating capital $=$ Net Investment + Depreciation and Amortization

\subsection{Shareholder Wealth}

Shareholder wealth is measured by the market value of a company. Market value of a company also relates the firm's stock price to its earnings, cash flow and book value per share. This is because it gives management and future prospects. For example, if the liquidity, asset management, debt management, and profitability provide good performance, then market value will be high, and the stock price is high (Brigham \& Ehrhardt, 2004). Market value of a company is measured by Price-to-Book Ratio (P/B ratio) provided by the Stock Exchange of Thailand (SET). In this study, multiple-regression modeling is used to determine the relationship between independent variables and a dependent variable. The statistical model for the analysis is as follows. 
Minority Shareholder Investment Protection $=\beta 0+\beta 1$ (Non-controlling shareholders) $+\beta 2$ (Corporate Governance) $+\beta 3$ (Cash flow) $+\beta 4$ (Shareholder Wealth) + Error

\section{The Findings}

The results of the study derived from the testing of four hypotheses refer to the investigation of the relationship between independent variables and dependent variable. Independent variables are non-controlling shareholders, corporate governance, free cash flow, and shareholder wealth. Dependent Variable is minority shareholder investment protection. The overview findings present the factors that support minority shareholder investment protection. They are corporate governance, free cash flow, and shareholder wealth. However, non-controlling shareholders inhibits the protection of minority shareholder investment. The reasons are provided in the following discussion and suggestion.

\subsection{Why Do Non-Controlling Shareholders Prevent Minority Shareholder Rights Protection?}

Hypothesis 1 proposes that non-controlling shareholders have positively correlated with minority shareholder investment protection. The result rejects this hypothesis because the testing shows non-controlling shareholders have significantly negative relationship with minority shareholder investment protection (standardized coefficients beta -0.155 and p-value 0.050).

The findings reveal the limitation of the theory of separation of management and control and agency theory. The presence of non-controlling shareholders increases the separation between managers and shareholders, which minimizes a conflict of interests between management and shareholders (Eisenhardt, 1989). This is because noncontrolling shareholders prevent the controlling ownership system, which supports controlling managers who exploit resources of company based on their self-interests (Eisenhardt, 1989). The results of this study also suggested controlling shareholders performed better than noncontrolling shareholders for improving minority shareholder investment protection.

The findings of this study are consistent with some research in emerging markets that suggests controlling shareholders are likely to protect minority shareholders. This is because controlling owners enhance corporate financial performance in order to increase dividend payout for themselves, and minority shareholders are benefit by-product of the dividend payout (Franklin A, 2005). Controlling shareholders do not want to lose their position in management. That is why they encourage anti-takeover from outsiders by improving corporate performance (Shleifer \&
Vishny, 1997). This finding is also consistent with controlling owners in Japan where families do not expropriate the rights of minority shareholders because they are stewards (Sakawa \& Watanabel, 2019). However, agency theory argues that shareholder interests require protection by separating ownership and management. Stewardship theory argues shareholder interests are maximized by increasing ownership concentration. Results of this study fail to support agency theory and provide some support for stewardship theory (Donaldson \& Davis, 1991). This is because stewardship theory views controlling shareholders as "models of man" which originate in organizational psychology and organizational sociology. Controlling shareholders are conceived as being motivated by a need to achieve, to gain intrinsic satisfaction through successfully performing inherently challenging work, to exercise responsibility and authority, and thereby to gain recognition from peers and bosses (Davis, Schoorman, \& Donaldson, 1997; Donaldson \& Davis, 1991).

\subsection{The Factors That Promote the Protection of Minority Shareholder Investment}

The results of study suggest three factors encourage the protection of minority shareholder rights. They are corporate governance, free cash flow, and shareholder wealth.

\subsubsection{Corporate Governance and the Protection of Minority Shareholder Investment}

Hypothesis 2 tests that corporate governance has positively correlated with minority shareholder protection. The results support the hypothesis. The results of this study show that corporate governance has positive correlated with minority shareholder investment protection (standardized coefficients beta 0.17 and p-value 0.031 ). The findings are consistent with the explanation of corporate governance theory. This is because corporate governance is the system that controls management of company to reduce a conflict of interests between managers and shareholders (Shleifer \& Vishny, 1997). When managers perform good corporate governance, they represent incentive to provide good accountability for shareholders in response to good corporate performance and bring adequacy returns to shareholders (Shleifer \& Vishny, 1997; Udayasankar \& Das, 2007).

\subsubsection{Free Cash Flow and the Protection of Minority Shareholder Investment}

Hypothesis 3 predicts that free cash flow has positively correlated with minority shareholder investment protection. The results accept the hypothesis (standardized coefficients beta 0.214 and p-value 0.007). The findings of this study 
are reflected in the theory of free cash flow that suggests a conflict of interests between managers and shareholders is declining when managers generate substantial free cash flow rather than invest in inefficient projects or below the cost of capital. The results of this study also show that free cash flow had a positive relationship with minority shareholder investment protection. The implication of this study reveals that, when the management of firm create substantial free cash flow, it would benefit return to minority shareholders.

\subsubsection{Shareholder Wealth and the Protection of Minority Shareholder Investment}

Hypothesis 4 predicts that shareholder wealth has positively correlated with minority shareholder investment protection. The results accept the hypothesis (standardized coefficients beta 0.318 and p-value 0.000 ). The result shows the growth of share market price supports shareholders'wealth maximization, which safeguards the protection of minority shareholder investment. This is because non-controlling shareholders encourage corporate governance that increases the wealth of shareholders by maximising shareholder wealth (Sturm \& Nüesch, 2019). Corporate governance safeguards non-controlling shareholders protection because they have the power to monitor management, which limits insidertrading of controlling shareholders (Croci \& Petmezas, 2010).

\section{Conclusion and Limitation}

The theory of separation between management and control and agency theory has limitations in explaining why non-controlling shareholders or a dispersed ownership system inhibits the improvement of minority shareholder rights protection. This is because this study investigated different population such as SME companies in the MAI market of Thailand where the size of companies are different from large companies, which are the majority population researched in the previous studies. The findings of this study support the ideas that controlling shareholders of SME companies are crucially focused on improving corporate financial performance by monitoring management in order to defend themselves from takeover, and increase their returns from investment, which is associated with increasing their earning from dividend (Franks \& Mayer, 1994; Weinstein \& Yafeh, 1998). This is because this research finds the presence of the factors that improve the protection of minority shareholders, which are corporate governance, free cash flow, and shareholder wealth. The evidence demonstrates that the roles of controlling shareholder on stewardship responsibilities are important to enhance corporate governance that would benefits minority shareholder by-product. Future research should focus on how controlling shareholders promote stewardship for protecting minority shareholder interests.

\section{References}

Aguilera, R. V., \& Cuervo-Cazurra, A. (2004). Codes of Good Governance Worldwide: What is the Trigger? . Organization Studies, 25(3), 417-446. doi: 10.1177/0170840604040669

Berle, A., \& Means, G. (1932). The Modern Corporation and Private Property. New York, NY: World Inc.

Bougie, R., \& Sekaran, U. (2016). Research method for business: A skill building approach. West Sussex, UK.: John Wiley \& Sons.

Brigham, E. F., \& Ehrhardt, M. C. (2004). Financial Management: Theory \& Practice. The United States of America: Thomson South-Western.

Claessens, S., Djankov, S., Fan, J., \& Lang, L. (1999). Expropriation of minority shareholders in East Asia. Washington, DC: The World Bank.

Croci, E., \& Petmezas, D. (2010). Minority Shareholders' Wealth Effects and Stock Market Development: Evidence from Increase-in-Ownership M\&As Journal of Banking \& Finance, 34(3), 681-694. doi: https://doi.org/10.1016/j. jbankfin.2009.09.003

Davis, J. H., Schoorman, F. D., \& Donaldson, L. (1997). Toward a Stewardship Theory of Management. Academy of Management Review, 22(1), 20-47.

Donaldson, L., \& Davis, J. H. (1991). Stewardship Theory or Agency Theory: CEO Governance and Shareholder Returns. Australian Journal of Management, 16(1), 49-65.

Eisenhardt, K. M. (1989). Agency theory: An Assessment and Review Academy of Management Review, 14(1), 57-74.

Eldomiaty, T. I., \& Choi, C. J. (2006). Corporate governance and strategic transparency: East Asia in the international business systems. Corporate Governance, 6(3), 281-295.

Franklin A. (2005). Corporate Governance in Emerging Economies. Oxford Review of Economic Policy, 21(2), 164-177.

Franks, J., \& Mayer, C. (1994). The ownership and control of German corporations. London Business School UK.

Jensen, M. C. (1986). Agency Costs of Free Cash Flow, Corporate Finance, and Takeovers. American Economic Review, 76(2), 323-329.

Jensen M. C., \& Meckling, W. (1976). Theory of the firm: Managerial behavior, Agency costs and Ownership Structure. Journal of Financial Economics, 3(4), 305-360.

Johnson, S., Booneb, P., Breachc, A., \& Friedmand, E. (2000). Corporate governance in the Asian financial crisis. Journal of Financial Economics, 58(1-2), 141-186.

Maher, M. E., \& Andersson, T. (1999). Corporate Governance: Effects on Firm Performance and Economic Growth: Organisation for Economic Co-operation and Development. 
Nam, S.-W., \& Nam, C. (2004). Corporate Governance in Asia: Recent Evidence from Indonesia, Republic of Korea, Malaysia, and Thailand. Manila, Philippines: Asian Development Bank.

OECD. (2015). G20/OECD Principles of Corporate Governance. Turkey: The Organisation for Economic Co-operation and Development.

Sakawa, H., \& Watanabel, N. (2019). Family control and ownership monitoring in Stakeholder-oriented corporate governance. Management Decision, 57(7), 1712-1728. https://doi. org/10.1108/MD-04-2018-0480

Shleifer, A., \& Vishny, R. W. (1997). A Survey of Corporate Governance Journal of Finance, 52, 737-738.

Siamwalla, A. (2001). Picking up the peices: Banks and corpoarte restructuring in post - 1997 Thailand. Paper presented at the The subregional Seminar on Financial and Corporate Sectors Restructuring in East and South-East Asia, Seol, Korea.

Stock Exchange of Thailand. (2020). Distribution of Minority Shareholdings (Free Float). Retrieved April 9, 2020, from https://www.set.or.th/en/regulations/simplified_regulations/ free_float_p1.html
Sturm, M., \& Nüesch, S. (2019). Strong shareholder rights, internal capital allocation efficiency, and the moderating role of market competition and external financing needs. Review of Managerial Science, 13(1), 93-111.

Sundaravej, T., \& Trairatvorakul, P. (1989). Experiences of financial distress in Thailand (pp. 33). Bangkok: The Bank of Thailand.

The Stock Exchange of Thailand. (2017). Structural Group of Indutries in MAI. Retrieved January 12, 2017, from: https:// www.set.or.th/mai/th/company/industry_group_p1.html

The Stock Exchange of Thailand. (2018). Data by Listed Company, 2018. Retrieved April 20, 2019 from: https://www.set.or.th/set/ commonslookup.do? language $=$ th $\&$ country $=\mathrm{TH}$

Udayasankar, K., \& Das, S. S. (2007). Corporate Governance and Firm Performance: the effects of regulation and competitiveness Corporate Governance: An International Review, 15(2), 262271.

Weinstein, D. E., \& Yafeh, Y. (1998). On the costs of a bankcentered financial system: Evidence from the changing main bank relations in Japan. Journal of Finance, 53(2), 635-672. 


\section{Appendix}

Table 1: Model Summary

\begin{tabular}{|c|c|c|c|c|}
\hline Model & $\mathbf{R}$ & R Square & Adjusted R Square & Std. Error of the Estimate \\
\hline & $.472^{\mathrm{a}}$ & .222 & .199 & 41.82188 \\
\hline
\end{tabular}

Table 2: ANOVA

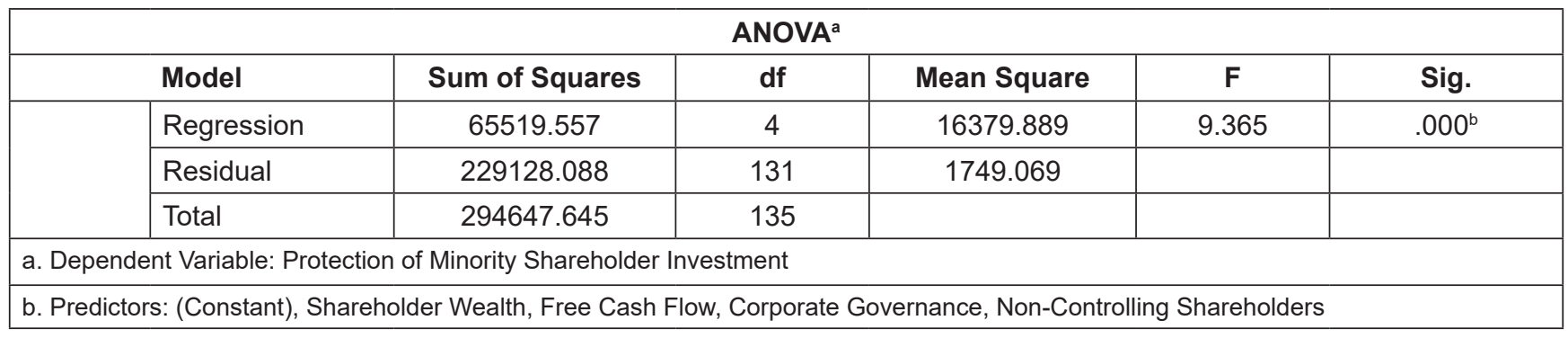

Table 3: Coefficients of Minority Shareholder Rights Protection Model

\begin{tabular}{|c|c|c|c|c|c|c|c|}
\hline \multicolumn{8}{|c|}{ Coefficients $^{a}$} \\
\hline \multirow[t]{2}{*}{ Model } & \multicolumn{2}{|c|}{$\begin{array}{l}\text { Unstandardized } \\
\text { Coefficients }\end{array}$} & \multirow{2}{*}{$\begin{array}{c}\text { Standardized } \\
\text { Coefficients }\end{array}$} & \multirow[t]{2}{*}{$\mathbf{t}$} & \multirow[t]{2}{*}{ Sig. } & \multicolumn{2}{|c|}{$\begin{array}{l}\text { Collinearity } \\
\text { Statistics }\end{array}$} \\
\hline & B & Std. Error & & & & Tolerance & VIF \\
\hline (Constant) & -13.452 & 6.862 & & -1.960 & .052 & & \\
\hline $\begin{array}{l}\text { Non-Controlling } \\
\text { Shareholders }\end{array}$ & -15.616 & 7.884 & -.155 & -1.981 & .050 & .969 & 1.032 \\
\hline Corporate Governance & 4.409 & 2.019 & .170 & 2.183 & .031 & .975 & 1.026 \\
\hline Free Cash Flow & .060 & .022 & .214 & 2.752 & .007 & .981 & 1.019 \\
\hline Shareholder Wealth & 1.097 & .268 & .318 & 4.096 & .000 & .986 & 1.014 \\
\hline \multicolumn{8}{|c|}{ a. Dependent Variable: Minority Shareholder Investment Protection } \\
\hline \multicolumn{8}{|c|}{ b. Predictors: (Constant), Shareholder Wealth, Free Cash Flow, Corporate Governance, Non-Controlling Shareholders } \\
\hline \multicolumn{8}{|c|}{$\begin{array}{l}\text { The results of this study have no Multi-Collinearity exists because Tolerance is more than } 0.10 \text { and VIF is less than } 10 \text {. This finding } \\
\text { indicates all variables provided no bias for statistical analysis because Multi-Collinearity complicates the interpretation of the variate which } \\
\text { is more difficult to ascertain the effect of any single variable and owing to their relationships (Bougie \& Sekaran, 2016) }\end{array}$} \\
\hline
\end{tabular}

